\title{
LOCALIS
}

\section{Evidence in Civil Law - Denmark}

Authors:

Frederik Waage

Michael Herborn 


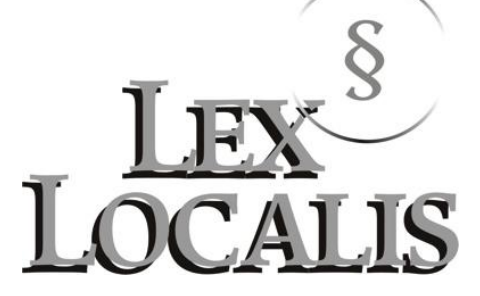




\section{(C) Institute for Local Self-Government and Public Procurement Maribor}

All rights reserved. No part of this book may be reprinted or reproduced or utilized in any form or by any electronic, mechanical, or other means, now known or hereafter invented, including photocopying and recording, or in any information storage or retriveal system, without permission in writing from the publisher.

Title: $\quad$ Evidence in Civil Law - Denmark

Authors: Frederik Waage, Michael Herborn

First published 2015 by

Institute for Local Self-Government and Public Procurement Maribor

Grajska ulica 7, 2000 Maribor, Slovenia

www.lex-localis.com,info@lex-localis.com

Book Series: Law \& Society

Series Editor: Tomaž Keresteš

CIP - Kataložni zapis o publikaciji

Narodna in univerzitetna knjižnica, Ljubljana

$347(489)(0.034 .2)$

WAAGE, Frederik

Evidence in civil law - Denmark [Elektronski vir] / Frederik Waage, Michael Herborn. - El. knjiga. Maribor : Institute for Local Self-Government and Public Procurement, 2015. - (Lex localis) (Book series Law \& society)

Način dostopa (URL): $\underline{\text { http://books.lex-localis.press/evidenceincivillaw/denmark }}$

ISBN 978-961-6842-46-4 (epub)

1. Herborn, Michael

281107712

Price: free copy

This project has been funded with support from the European Commission. This publication reflects the views only of the authors, and the Commission cannot be held responsible for any use which may be made of the information contained therein.

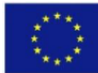

With the support of the Civil Justice Programme of the European Union 


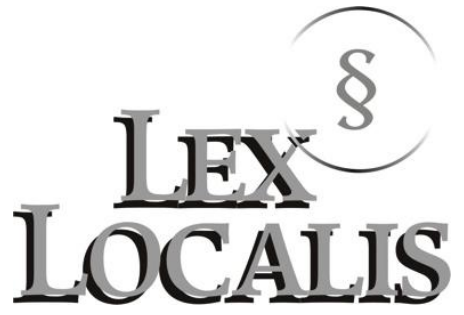

\title{
Evidence in Civil Law - Denmark
}

\author{
Frederik Waage \\ Michael Herborn
}





\title{
Evidence in Civil Law - Denmark
}

\section{FREDERIK WAAGE \& MICHAEL HERBORN}

\begin{abstract}
Danish civil procedure is based on a number of procedural law principles that affect the taking of evidence, including the principle of party presentation, the principle of disposition, and the principle of free assessment of evidence. The nature of Danish procedural law tends towards the adversarial model rather than the inquisitorial model. Evidence is taken during the hearing and the principle of directness applies to the procedure. Danish civil procedure is governed by the 1916 Administration of Justice Act, which was originally strongly influenced by German law. The role of the judge is to lead the process and also to intervene in proceedings when uncertainty exists, rather than just to facilitate the process by ensuring the parties abide by the laws of civil procedure.
\end{abstract}

KEYWORDS: • procedural law $\bullet$ due process $\bullet$ fair trial $\bullet$ civil procedure $\bullet$ law of evidence $\bullet$ free assessment $\bullet$ access to justice

CORRESPONDENCE ADDRESS: Frederik Waage, LL.M., University of Southern Denmark, Department of Law, Campusvej 55, DK-5230 Odense M, Denmark, email: fwa@sam.sdu.dk. Michael Herborn, Ph.D. fellow, University of Southern Denmark, Department of Law, Campusvej 55, DK-5230 Odense M, Denmark, email: mher@sam.sdu.dk. 


\section{Frederik Waage Michael Herborn}

Author Biography Frederik Waage is a research assistant at University of Southern Denmark and a former attorney-at-law with licence to the Danish Bar. He has also been engaged as an external lecturer at University of Copenhagen for a number of years. Mr Waage is currently working on a project on procedural law and administrative disputes, including the role of the Danish state attorney as a party in civil and administrative litigations in Denmark. The study, scheduled for completion in 2016, includes comparative research (mainly covering Germany, UK, US and other Scandinavian countries), revolving around the role of the judge and the state attorney in the court procedure. $\mathrm{Mr}$ Waage is in charge of the general course Constitutional Law at University of Southern Denmark and he regularly teaches procedural law to Master's students.

\section{Michael Herborn}

Author Biography Michael Herborn is a PhD fellow at the University of Southern Denmark, with a focus on energy law, environmental law, and law and economics. His research centres upon municipal engagement in energy planning from a legal perspective, and forms part of a larger research project on district heating technologies - 4DH - financed by the Danish Council for Strategic Research. Mr Herborn holds law degrees from the University of Copenhagen (LLM) and the University of Oxford (BA (Hons) Jurisprudence), as well as a Master in International Business from the University of Sydney. 


\section{Preface}

This report on the handling of evidence in the Danish legal system was mainly drafted in the first months of 2014 at the Department of Law at The University of Southern Denmark as part of the research project Dimensions of Evidence in European Civil Procedure, which was financed by the Civil Justice/Criminal Justice Programme of the European Union. In keeping with the other reports that make up this project, the focus here is upon general principles of law rather than specific legislative provisions. We are in favour of this approach. In the words of Neil Andrews, a well-known UK scholar of comparative civil procedure, the general principles may be considered an "antidote to the numbing and bewildering complexity, detail, and technicality which characterise many national procedural rule books".

In the process of drafting this material, it has been a privilege to work together with the organising staff from The University of Maribor. We are grateful that Dr. Vesna Rijavec from The University of Maribor allowed us to contribute to this project in the first place and we appreciate the cooperation with the tireless Slovenian team. Thanks to Katja Drnovšek from the University of Maribor for clever and practical guidance from the very beginning of this project.

Odense and Copenhagen, 27 May 2015

Frederik Waage

Michael Herborn 

Evidence in Civil Law - Denmark

F. Waage \& M. Herborn

\section{Contents}

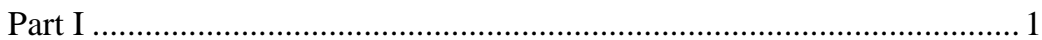

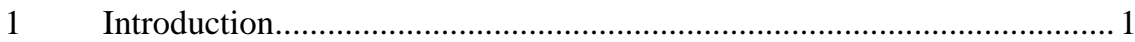

2 Fundamental Principles of Civil Procedure …….................................... 2

2.1 Party Presentation Principle and Principle of Investigation........................ 2

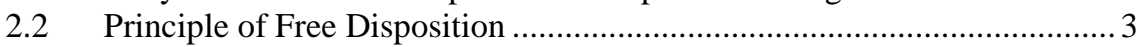

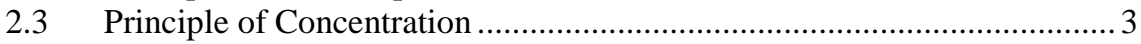

2.4 No Inquisitorial Procedure in Danish Law ............................................ 4

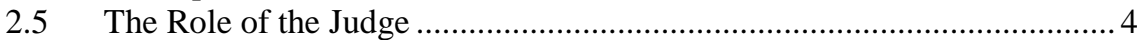

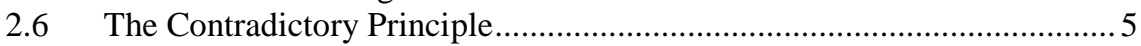

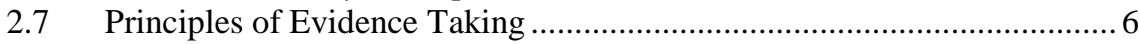

2.8 Principles that Guides the Judge in the Taking of Evidence ...................... 7

2.9 The Contradictory Principle....................................................................... 7

2.10 Failure to Appear Before the Court ……….............................................. 8

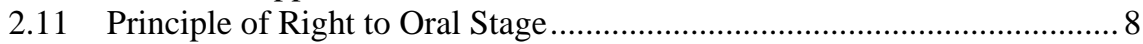

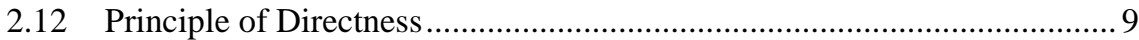

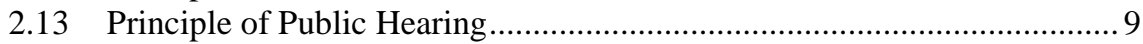

3 General Principles of Evidence Taking ............................................... 10

3.1 Free Assessment of Evidence ……………......................................... 10

3.2 The Principles of Material and Formal Truth ......................................... 10

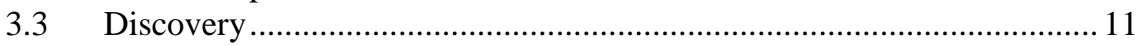

3.4 The Right to Put Forward New Facts and Evidence (ius

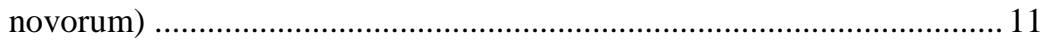

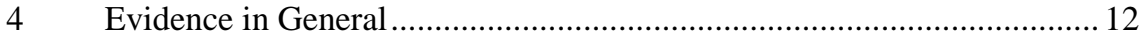

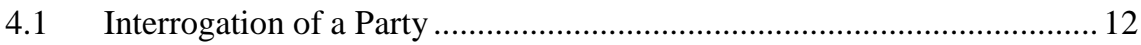

4.2 Duty to Speak the (Full) Truth............................................................ 13

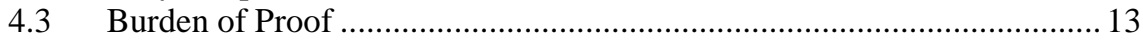

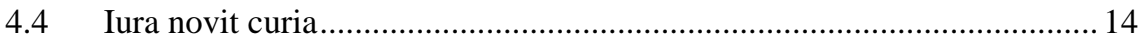

4.5 Re-opening of the Pre-trial Procedure ..................................................... 14

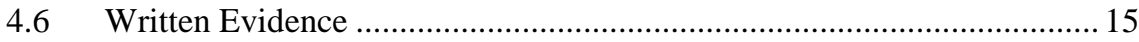

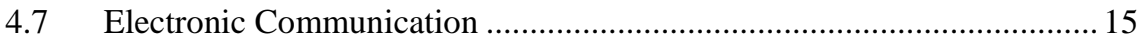

$5 \quad$ General Rule on the Burden of Proof................................................... 16

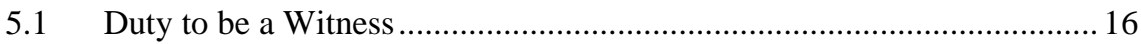

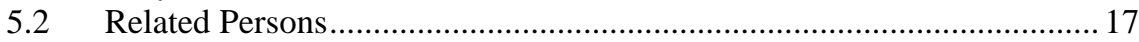

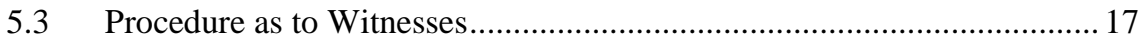

5.4 Obtaining Evidence from Witnesses..................................................... 19

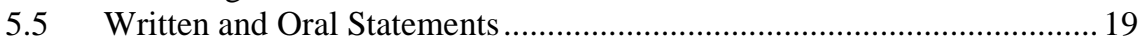

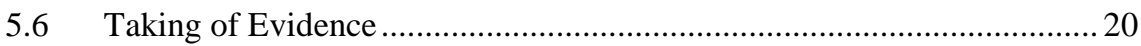

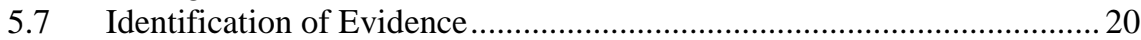

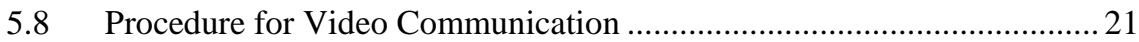

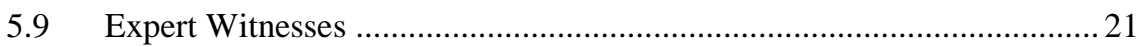

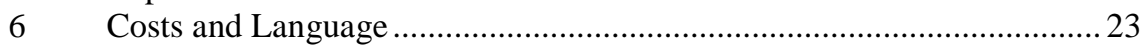


ii | Contents

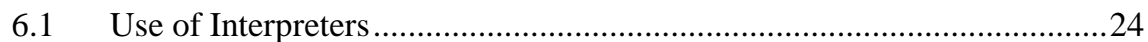

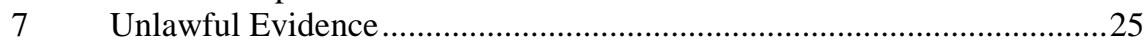

7.1 The Principle of Free Evidence .......................................................25

Part II - Synoptical Presentation ...................................................27

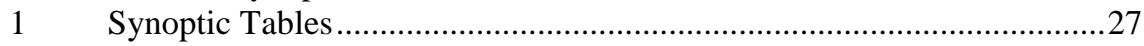

1.1 Ordinary/Common Civil Procedure Timeline .....................................27

1.2 Basics about Legal Interpretation in Denmark Legal System ..................28

1.3 Functional Comparison ................................................................28

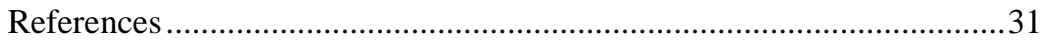


Evidence in Civil Law - Denmark

F. Waage \& M. Herborn

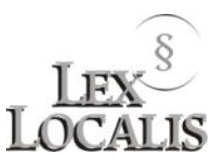

\section{Part I}

\section{$1 \quad$ Introduction}

Danish procedural law is primarily regulated under the Danish Administration of Justice Act ("the Act") ${ }^{2}$. The Act regulates civil and criminal procedural law. It gives a legal home to a number of principles of procedural law that have either previously existed in Danish law or emigrated to Denmark from German procedural law, where Danish procedure takes much of its inspiration from. ${ }^{3}$ It follows from some of the early motivations behind the Act, adopted in 1916, that Danish courts should step into character exercising a "gap-filling" function when necessary, when the text of the law is unclear. ${ }^{4}$ Today, it is acknowledged that the courts must follow the law, but in order to fulfill their task, the courts are also expected to be proactive and create new law by interpretation and application of the provisions of the Act in light of, inter alia, the general principles of law. The role of the judge is to lead the process and also to intervene in proceedings when uncertainty exists, rather than just to facilitate the process by ensuring the parties abide by the laws of civil procedure. That being said, in general, the parties enjoy a high degree of flexibility in procedural matters, with Danish civil procedure centring upon the principle of free disposition. In the context of Danish civil procedure, free disposition is defined as a principle which "in general expresses the right of the parties to freely dispose over the case and - to some degree - also the form of the procedure." A distinction is made between the principle of free disposition and the principle of officiality. The principle of officiality applies in cases where the court on its own initiative retrieves information or decides to investigate a question on its own. ${ }^{6}$ A few examples of this exist in Danish civil procedure law, primarily in family law matters, but this must be seen as the exception to the rule - as detailed below.

The party-led process under the principle of free disposition corresponds to one of the other key principles governing Danish civil procedure, party presentation, whereby

\footnotetext{
${ }^{2}$ In Danish: Retsplejeloven, cf. Lovbekendtgørelse nr. 1139 af 24. september 2013. For a general presentation of Danish civil procedure in English, see Erik Werlauff, Civil Procedure: Denmark, $3^{\text {rd }}$ edition, 2010.

${ }^{3}$ This can be seen in the first draft of the Danish Administration of Justice Act from 1869, which was strongly influenced by German procedural law. On the German influence, see e.g. Finn Taksøe Jensen, Materiel Procesledelse, 1976, p. 96.

${ }^{4}$ Johannes Nellemann, Foreløbigt Udkast til Lov om Rettergangsmaaden i borgerlige Domssager med Motiver, 1869 , p.87.

${ }^{5}$ See Bernhard Gomard and Michael Kistrup, Civilprocessen, $7^{\text {th }}$ edition, 2013, p. 31.

${ }^{6}$ Bernhard Gomard and Michael Kistrup, supra note 5, p. 30.
} 
responsibility for fact-finding lies with the parties, as is described below. While the term "adversarial" is not used in Danish civil procedure, it follows from the high level of party involvement that the Danish system will in most cases resemble an adversarial process.

\section{Fundamental Principles of Civil Procedure}

\subsection{Party Presentation Principle and Principle of Investigation}

As noted above, there is no corresponding term to "adversarial" in Danish procedural law. However, the nature of Danish procedural law tends towards the adversarial model rather than the inquisitorial model. According to an international study of comparative law led by Remco van Rhee and Remme Verkerk, a purely adversarial procedure involves a judge who acts as an umpire who does nothing but listen to what the parties put before him and who declares $a$ "winner" in his judgment. ${ }^{7}$ On the other hand, the inquisitorial model is described as a procedure where the judge has an active, dominant role, and for example is involved in the framing of the issues and the gathering of evidence. ${ }^{8}$ While also acknowledging that neither extreme exists in practice, Danish civil procedure is generally much closer to the adversarial model than the inquisitorial model. The divisions of responsibility of the case between the parties and the judge generally follow the ubiquitous so called principle of party-presentation, (in Danish "forhandlingsprincippet") ${ }^{9}$ and the rarely seen principle of investigation (in Danish "Undersøgelsesprincippet") ${ }^{10}$

The party-presentation principle is codified in section 338 of the Act, which states that the court's judgment must be exclusively based upon the claims of the parties and pieces of information which are brought before the court by the parties. In general the court does not have the power to bring further pieces of information into the case. ${ }^{11}$ The court may not give a party to the proceedings more than he has claimed (ultra petita) and it can only assess arguments that the party has brought before the court, or arguments that are mandatory under the law for the court to consider, cf. section 338 .

However, under section $456 \mathrm{~h}(1)$ of the Act, in cases concerning the determination of paternity or joint maternity of a child, the court is responsible for investigating the facts of the case. According to this provision, the court decides on its own whether parties or witnesses shall be questioned and whether experts shall be consulted and evidence taken. As such, the inquisitorial principle can also be found in Danish law. These cases, including cases involving the determination of paternity of a child, are handled "ex officio". ${ }^{12}$ Nearly all other cases, regardless of whether they involve private or public

${ }^{7}$ See C.H. Remco van Rhee and Remme Verkerk in Jan M. Smits, Elgar Encyclopedia of Comparative Law, $2^{\text {nd }}$ edition, 2012, p. 146.

${ }^{8}$ Ibid.

${ }^{9}$ This principle corresponds to the German Verhandlungsmaxime.

${ }^{10}$ This principle corresponds to the German Untersuchungsmaxime.

${ }^{11}$ Bernhard Gomard and Michael Kistrup, supra note 5, p. 29.

${ }^{12} \mathrm{Cf}$. section $456 \mathrm{~h}$, which states that the court investigates the merits of the case. 
law, or for instance EU law or human rights issues, are handled by the private parties in accordance with the party-presentation principle.

\subsection{Principle of Free Disposition}

The principle of free disposition is a key principle in Danish civil procedure. It expresses a general understanding of the relationship between procedural and substantive law. Under the principle, parties maintain control of their case, even during the hearing phase where settlements are strongly encouraged by the court. ${ }^{13}$ The principle of free disposition is implicitly codified in section 338 of the Act.

The parties are limited in their disposal over cases that are subject to statutory restrictions, for instance rules regulating child custody. Thus even if both parties agree on an issue related to child custody, for instance the future home of a child after a divorce, mandatory law requires that the court investigates whether it is in the best interest of the child to change school and residence (ex officio). In these cases the court is allowed and expected to investigate even facts that were not presented by the parties if such facts are missing from the case files. For instance the judge may make a phone call to the school of the child to verify the validity of a statement from one of the parents concerning the health of the child. Furthermore, in all civil disputes, the parties only have limited control over the form of the case, although some of the formal rules such as rules regarding a forum and enforcement of time limits can be open for negotiation between the parties. ${ }^{14}$

\subsection{Principle of Concentration}

According to section 344 of the Act, the court decides which facts must be properly established before the case can be decided. In order to reduce costs and save time for the parties and the court, it is required that the process is concentrated. Thus, the parties must proceed with the case within a reasonable timeframe and arrange their negotiations around as few court meetings (including hearings) as possible. Arguments and claims should be brought before the court as soon as possible and new claims and arguments should only in exceptional circumstances be allowed. ${ }^{15}$ The trial is divided between a pre-trial stage, where the case is taken up by the court, and a deliberation stage. While the parties are free to expand their claims and present new arguments and evidence before the end of the pre-trial stage, new arguments and evidence can only be brought before the court under exceptional circumstances once the court has decided to end the pre-trial stage. ${ }^{16}$

If a party wishes to expand claims or pleas made during the pre-trial procedure or to make submissions which have not been made during the pre-trial procedure, the party must notify the court and the opposing party. The opposing party then has one week to

\footnotetext{
${ }^{13}$ Bernhard Gomard and Michael Kistrup, supra note 5, p. 621.

${ }^{14}$ Ibid.

${ }^{15}$ Bernhard Gomard and Michael Kistrup, supra note 5, p. 29.

${ }^{16}$ Bernhard Gomard and Michael Kistrup, supra note 5, p. 325.
} 
submit his comments to the court and the other party. Thereafter the court will make its decision on whether or not a re-opening of the pre-trial procedure is possible, after which the new evidence may be added, cf. section 358 of the Act.

\subsection{No Inquisitorial Procedure in Danish Law}

The inquisitorial principle does not apply to Danish civil procedure. In the $19^{\text {th }}$ Century, the inquisitorial principle regulated the proceedings in criminal cases in Denmark. Today, however, also in criminal cases, the parties (normally represented by the state attorney and the attorney of the defendant) present the case before the judge.

However, in stark contrast to the civil court judge, the criminal court judge is tasked with establishing the material truth. Thus, according to Section 867 of the Act, the judge is "entitled and obligated to pose questions to the person who is being questioned, whenever it is in the interest of establishing the truth." In civil litigations the judge is not empowered to take in evidence on his own hand. The civil judge may suggest to the parties to put forward evidence according to Section 339 of the Act, but if the parties do not participate, the judge is not entitled to search for evidence of his own accord. In the event that a judge suggests that a party brings a certain piece of evidence forward, this will normally act as a powerful incentive for the parties to bring this piece of evidence to the table. Thus in reality the judge has a strong informal power also through "the desire to get on the judge's good side."

The judge is, however, always limited by the fact, that he is bound to act impartially. By posing appropriate questions, the presiding judge can provoke the parties to reformulate or process new pieces of documents or evidence. Thus, the judge is allowed to propose that the parties make certain amendments to their claims or arguments, even though it is entirely up to the parties to take the necessary steps to make the final amendments. ${ }^{17}$ It is beyond doubt that such activity in "borderline" cases may be the proverbial straw that breaks the camel's back, bearing in mind the judge's role as impartial umpire. This could for instance be the case in a situation where the presentation is handled by an inexperienced lawyer who has failed to discover that the case could be won simply by referring to an otherwise well-known provision in the legislation. Therefore the role of the judge will often be to strike a delicate balance in the interference, in order to assure that the neutrality of the court is not compromised.

\subsection{The Role of the Judge}

In civil cases, the judge takes the role of leader of the negotiations during the hearing. It is generally believed that this role can be conducted more or less actively, depending on the case and the parties. ${ }^{18}$ According to Section 339, the judge must actively participate in establishing that the grounds of the decision are sufficiently clear and in line with the wishes and interests of the parties. The judge's position as negotiator implies that he

\footnotetext{
${ }^{17}$ Ibid.

${ }^{18}$ Bernhard Gomard and Michael Kistrup, supra note 5, p. 582.
} 
must lead the formal part of the process as president. ${ }^{19}$ This follows from section 150 of the Act which states the following:

"The presiding judge presides over the proceedings. He decides the order of the individual stages of the proceedings, save where otherwise provided for by this Act. No person is allowed to speak unless permitted by the presiding judge, and a speaker who refuses to comply with his directions may be excluded from speaking. Where possible, he will seek to remove anything which slows the progress of the proceedings to no purpose, and end the individual stages of the proceedings when he finds the issue before the court to have received sufficient attention."

The tasks of the preceding judge also include, amongst others, the enforcement of the rules in the Act, determination of time of meetings, delivery of written documents, and establishing the speaking order of the lawyers in the proceedings. ${ }^{20}$

Even after the proceedings have ended (at the time when the parties await the delivery of the judgment), the judge is entitled to re-open the case if it is found unfitting to place a judgment based on what has been presented before the court. ${ }^{21}$

The neutrality of the court is generally claimed as the most important argument in favour of the strong position of the party-presentation principle in Danish law. ${ }^{22}$

In first instance cases, the judge is required to assist a party who is not represented by a lawyer, cf. section 339(4) of the Act. In general, this duty does not apply to second and third instance judges. In all instances, the judge has the possibility to require that the party is represented by an attorney, cf. section 259 of the Act. It is generally believed that if a party, because of a misunderstanding or perhaps due to simple negligence, has forgotten to put forward an argument that could be of importance to the case, a judge who is aware of this, should ask whether the party wishes to reconsider his claims or put forward the (obvious) argument. Thus, the dominating view is that the lack of knowledge of one party to the law or the facts, or misunderstandings of the rules and their application, should not result in that party losing at trial. ${ }^{23}$

\subsection{The Contradictory Principle}

The contradictory principle plays an important role in Danish civil procedure. According to the traditional definition of this principle, the parties must have access to all the facts, including the claims and arguments that are a part of the case. ${ }^{24}$ Art. 6 of The European Convention of Human Rights has influenced the application of the Danish principle of contradiction. In line with the jurisprudence of The European Court of Human Rights, the general understanding is that each party must have the possibility

\footnotetext{
${ }^{19}$ Ibid.

${ }^{20}$ Ibid.

${ }^{21}$ Bernhard Gomard and Michael Kistrup, supra note 5, p. 583.

${ }^{22}$ Taksøe-Jensen, supra note 3, p. 31.

${ }^{23}$ Bernhard Gomard and Michael Kistrup, supra note 5, p. 585.

${ }^{24}$ See Bo Von Eyben, Juridisk Ordbog, 13. Edition, p. 223.
} 
to become familiar with and comment on all written material and all pieces of evidence that are brought forward at trial, regardless of whether these items do not appear to be new or capable of changing the case. ${ }^{25}$ In practice, lawyers inform each other about any relevant correspondence with the court. Otherwise, the court is responsible for ensuring that the information is brought to the attention of each party. ${ }^{26}$

Danish rules on civil procedure also apply to cases between private parties and public authorities. However, in recent case law in this area, the Danish Supreme Court has in some ways construed the principle of contradiction pragmatically. For example, in a recent case, an agreement was made between the parties, where it was accepted that confidential documents which citizens would normally not be entitled to gain access to in a traditional administrative procedure, were provided to the court exclusively, and not to the private party. ${ }^{27}$ It can be argued, that in this case, the Supreme Court allowed the principle of free disposition to limit the application of the principle of contradiction.

\subsection{Principles of Evidence Taking}

While the general rule under section 340(1) of the Act limits the presentation of evidence to the main trial proceedings, the same section permits the court to sanction evidence taking before a trial is held if this appears appropriate according to the circumstances of the case. For instance, this could be if there is a risk that evidence may be lost, damaged or destroyed if a party is required to wait until trial before presenting their evidence. It is also possible to actually set the court, and thereby secure the evidence, so that the judges and the parties, for example, visit a site or question a witness, before it has even been decided that a court case will come to pass. The parties thus may have the possibility to secure evidence before the beginning of the hearing. This so called isolated taking of evidence is considered cost efficient because the validity of possible claims can be cleared already outside the court on factual grounds. ${ }^{28}$

Danish procedural law is governed by the principle of free presentation of evidence, with no strict rules on the submission of evidence. As already mentioned, in accordance with the principle of party-presentation and the principle of free disposition, it is the parties that control the evidence. ${ }^{29}$ The court may, according to section 339(3) of the Act, ask the parties to present certain pieces of evidence that are available to them, but cannot force the parties to do so. The court can also ex officio cut off evidence which it deems to be irrelevant in deciding the case, cf. section 341. Examples of superfluous evidence include evidence that the court may not use as basis for a decision, for example summaries of negotiations that could have resulted in an out of court settlement. $^{30}$

${ }^{25}$ Ulrik Rammeskov Bang Pedersen and Lasse Højlund Christensen, Den civile retspleje, 2010, p. 68.

${ }^{26}$ Ulrik Rammeskov Bang Pedersen og Lasse Højlund Christensen, supra, p. 434-435.

${ }^{27}$ See Ugeskrift for Retsvæsen, 2011, p. 616.

${ }^{28}$ Bernhard Gomard and Michael Kistrup, supra note 5, p. 482.

${ }^{29}$ Ulrik Rammeskov Bang Pedersen og Lasse Højlund Christensen, supra note 25, p. 461.

${ }^{30}$ Ulrik Rammeskov Bang Pedersen og Lasse Højlund Christensen, p. 462. 
In recent years, there has been a practice in the Danish Supreme Court towards allowing factual, but also judicial argumentation based on "one-sided" expert opinions drafted for the purpose of the trial. The ordinary system based on court-appointed expert witnesses (syn og skøn) is, however, still the leading tool for obtaining evidence. This procedure involves one or more expert inspections or professional appraisals of a particular event or object. $^{31}$

After the parties have brought their evidence before the court, the court decides, based upon these claims, which factual circumstances need to be established by the court in order for it to reach a judgment. The court evaluates the validity of witnesses, evidence etc. based on the general impression they make in court, without being bound by the specific rules of evidence. ${ }^{32}$

The method of free assessment of evidence can be considered in contrast to the assessment of proof, which follows rules that are more or less strictly based upon specific pieces of regulation related to the type of case. Free assessment of evidence can, however, be supported by principles of evaluation of evidence, including the principle of burden of proof. Thus, if it is established, that a party must prove certain factual circumstances, and if these are not proved, it can be held against the party.

\subsection{Principles that Guides the Judge in the Taking of Evidence}

Despite the principle of free assessment, the starting point for any determination of the applicable rules for evidence taking is the relevant laws in the case at hand. But if the law does not stipulate particular rules for how evidence should be evaluated, which will normally be the case, a variety of legal principles apply in order to help determine the facts. For instance, the burden of proof typically rests upon the party that states that an issue differs from normal procedure ("comply or explain"). Also, the party for whom it is easiest to secure a particular piece of evidence should shoulder the burden of proof for establishing the facts surrounding it. The burden of proof can also switch during the course of the trial.

If a right concerning the taking of evidence is violated, an interlocutory appeal of the question related to the taking of evidence can be brought before a higher instance.

\subsection{The Contradictory Principle}

The principle of equality is comprised in the structure of Danish civil procedure and it is connected to the principle of contradiction which is, for example, expressed by the equal division of party presentation of written materials: writ (stavning), statement of defence (svarskrift), etc. The principle of equality is also reflected in the oral procedure. Furthermore, the principle can be found in the rules on the judge's impartiality. For instance, according to Section 60 of the Act, the judge must not be related to any of the parties. Nevertheless, the principle of equality does not stand in the way of changes in

\footnotetext{
${ }^{31}$ Erik Werlauff, supra note 2, 2010, p. 122.

${ }^{32}$ Ulrik Rammeskov Bang Pedersen og Lasse Højlund Christensen, p. 467.
} 
case law. Thus, previous court cases do not bind the court, and judge made law can in principle be changed at any given time. ${ }^{33}$

\subsection{Failure to Appear Before the Court}

The failure of a party's representative to appear before the court has a number of consequences. A distinction is made between failure to appear before the court where the party has actively engaged in proceedings, which may for instance result in a shorter hearing combined with easier possibilities of a re-trial, and failure to attend where the party has acted with a general passivity or reluctance towards providing the court with a (full) testimony. In the latter instance, the court will state that there has been a failure to appear, which will normally result in a judgment to the benefit of the claimant, unless for instance the claim in the writ is unclear or manifestly wrong. ${ }^{34}$ The rules also apply if the party does not show up for a pre-trial hearing. If the claimant's representative does not show up, the court will refuse the case, cf. section 360 of the Act.

\subsection{Principle of Right to Oral Stage}

The principle of right to oral stage of procedure follows from article 65(1) of the Danish Constitution. In this provision it is stated that hearings must be public and that the principle of right to oral stage of procedure should be "a part of the procedure to the widest degree possible." The principle of right to oral stage of procedure has a high standing in Danish procedural law. It follows from this principle that the court makes its decision based on the oral presentation of the case in court, cf. section 148 of the Act. The principle of right to oral stage is supplemented by the principle of public hearing, first of all due to the assumption that a true public procedure could not take place on a written basis, and also simply because an oral procedure is considered more interesting and more likely to draw general interest from the public. ${ }^{35}$

Despite the constitutional guarantees of right to oral stage of procedure, Danish civil procedure also facilitates a written procedure. This procedure is normally applied when the court deals with some relatively precise questions where questioning of witnesses and party interrogation is generally not needed, cf. section 366(1) of the Act. Whether or not a written procedure can be applied in such cases is based on a concrete evaluation of the case at hand that also involves the question of whether the case has a specific public interest. Furthermore, written procedure is normally applied when the court deals with questions of formality, especially in case of interlocutory appeals, mainly due to the fact that presentation of evidence is rarely necessary in such cases. ${ }^{36}$

Denmark does not have any administrative courts and most administrative disputes are in fact handled outside the court system by administrative boards often led by judges. In contrast to the procedure at the ordinary courts, the procedure of the administrative boards is normally written. The possibilities for evidence taking are therefore limited. A

\footnotetext{
${ }^{33}$ Bernhard Gomard and Michael Kistrup, supra note 5, p. 31.

${ }^{34}$ See Section 352 (1), 360 (3) and 363 of the Act.

${ }^{35}$ Bernhard Gomard and Michael Kistrup, supra note 5, p. 127.

${ }^{36}$ Bernhard Gomard and Michael Kistrup, supra note 5, p. 560.
} 
decision from such a board can normally afterwards be brought before the ordinary courts.

\subsection{Principle of Directness}

As noted in section 2.6, in Danish civil procedure, the principle of directness states that the taking of evidence must occur according to the directions of the court and during the main trial proceedings. ${ }^{37}$ This is codified in section 340 of the Act. Depending on the circumstances, the court can decide that evidence taking, or parts of it, can take place before the hearing, which means that a transcript of the testimony or video or audio recordings are presented as an appendix to the case material. A major reason behind the application of the principle of directness is that the court must be able to hear witnesses etc. and then form their own opinions based upon their testimony before court.

Derogations from the principle of directness are for instance allowed when it is deemed practical and appropriate that witnesses are not required to travel to courts which are located far away from their residence. Doing so may lead to higher costs, and thus a decision is made based upon whether the inconveniences of not appearing before the court outweigh the benefits. For instance in one case from 2007, the High Court allowed a witness with permanent residence in Peru to give a testimony in a case involving bankruptcy before he went back to Peru after a stay in Denmark. The witness did not expect to return to Denmark for a number of years. The court therefore found that it was too inconvenient for the witness to be required to travel back to Denmark for the hearing that was scheduled after his departure. ${ }^{38}$ If the testimony is short and simple, it is also likely that the court will allow the interrogation to take place in isolation from the main hearing.

The higher courts, including The Supreme Court, may deal with evidence in the same manner as the city courts. Both appellate courts are entitled to take in new evidence. However new pieces of evidence are only occasionally dealt with by the Supreme Court. $^{39}$

\subsection{Principle of Public Hearing}

The principle of a public hearing is an important part of Danish civil procedure. It requires that the public has access to participate in the hearings. ${ }^{40}$ As already mentioned, Article 65 of the Danish Constitution states that the principle of a public hearing and the principle of right to oral stage should apply "to the widest degree possible." Thus

\footnotetext{
${ }^{37}$ Bo von Eyben, supra note 24, p. 394, Bernhard Gomard and Michael Kistrup, supra note 5, p. 670.

${ }^{38}$ See Ugeskrift for Retsvæsen, 2007, p. 2993.

${ }^{39}$ This is not the case in criminal cases where the Supreme Court does not deal with evidence directly, cf. Werlauff, supra note 2, p. 14. In these cases, The Supreme Court must base its evaluation of evidence on the facts that are established by the lower courts.

${ }^{40}$ Bo von Eyben, supra note 24, p. 60, Bernhard Gomard and Michael Kistrup, supra note 5, p. 561.
} 
according to Section 28(a)(1) of the Act, all court hearings are public, unless otherwise stated. This provision also ensures that journalists etc. are allowed to cover hearings in the media.

Witnesses may not hear the testimonies of other witnesses, expert witnesses or parties in the same case, before they have given their own testimony. ${ }^{41} \mathrm{~A}$ common expression used in Danish civil procedure is the term "closed doors". This term indicates that the case is closed to the general public. Doors may be closed in cases involving public morality, order in the courtroom, relations to foreign states or for other specific reasons, cf. section 29 (1) no. 1 and 2 of the Act. The court can decide to close the doors if a public hearing would inflict harm on any of the parties or a third person, also in situations where trade secrets are likely to be revealed, cf. section 29 (1), no. 3 of the Act. According to a common request of the parties, the court can close the doors if it is in the interest of a party and no particular interest speaks against this. Protection of negotiations for settlement between the parties is also a valid argument for closing the doors to the public.

\section{General Principles of Evidence Taking}

\subsection{Free Assessment of Evidence}

Danish law operates according to the principle of free assessment of evidence. The principle is traditionally defined as the opposite of statutory assessment of evidence, a form of assessment where the court is bound by mandatory legislation in its judgment. In modern Danish law, the parties will normally be bound by evidence which is brought before the court by the parties, according to the aforementioned principle of free disposition.

Aside from the rules on burden of proof as mentioned below, no "methodological guidance" can be said to direct the court in its assessment of evidence.

\subsection{The Principles of Material and Formal Truth}

The principle of material truth governs Danish criminal procedure, but normally this principle does not apply to Danish civil procedure. On the contrary, civil procedure is said to be regulated by the principle of formal truth. This implies that the court will establish a fact, which the parties may agree upon, even in cases where the court is fully aware that the claimed fact is not true. It would therefore not be correct to state that Danish civil procedure operates with a guarantee of truth-seeking.

The principle of material truth does, nevertheless, apply to a few areas which are specifically regulated in the Act, for example cases that concern the establishment of paternity and a few cases concerning divorce law etc. (see section 2.2 in the above).

${ }^{41}$ Bernhard Gomard and Michael Kistrup, supra note 5, p. 565. 
Nevertheless, the party controlled process also secures - at least to some degree - that the disputed facts are tested. In Danish literature on evidence, it has been suggested that each party supplements each other in a "competition" on the clearing of the facts, which in fact lead to a firm decision. ${ }^{42}$ As such, the judge's decision settles a competition between the parties (or rather the lawyers of the parties) which will normally reach a balanced result which can be considered to mean to reach the truth.

\subsection{Discovery}

According to section 298 of the Act, the Court may, if requested by one of the litigants, require the counterparty to provide a document that is at their disposal and will be relied upon in the course of the trial. The request will be rejected though if release of this document will result in the publication of information that the counterparty is exempted or prevented from presenting as a witness according to the rules set out in section 169172 of the Act (see below). If the counterparty refuses to present this evidence, the court, when assessing the evidence so as to come to a judgment, may consider the actions of the counterparty to constitute a procedural disadvantage to the requesting party, though no other sanctions apply.

\subsection{The Right to Put Forward New Facts and Evidence (ius novorum)}

According to section 356 and 358 of the Act, the court decides when the pre-trial procedure is closed. Section 356 states, inter alia, that the court will direct when the pretrial procedure is to be closed, and unless otherwise directed by the court, pre-trial procedures is deemed closed four weeks before the date fixed by the court for start of the main trial proceedings. Under subsection 356(3), it is further stated that if the court finds an additional pre-trial procedure necessary, it may direct that the pre-trial procedure be reopened. Under section 358, if a party wishes to expand the claims or pleas made during the pre-trial procedure, the party must notify the court and the counterparty. The same applies if the party wishes to make submissions that have not been made during the pre-trial procedure or to produce evidence that also was not specified during the pre-trial procedure. The consequence of this is in principle is that new evidence - as a starting point - cannot be presented to the court. One of the important reasons behind this preclusion is that a party should not lose a case because it has been taken by surprise by new evidence that it had no time to prepare for.

The court does not have the expertise to assess all kinds of evidence that may be presented before the court. Therefore, in Danish civil procedure, specific expert witnesses with the relevant technical or academic knowledge either participate as cojudges, or are appointed to conduct a survey of the issue, or are questioned as expert witnesses. ${ }^{43}$ Aside from investigating the main object of dispute at the trial, the expert witness may for instance inform the court about market standards, best practises within

\footnotetext{
${ }^{42}$ Henrik Zahle, Det juridiske bevis, 1976, p. 632.

${ }^{43}$ Bernhard Gomard and Michael Kistrup, supra note 5, p. 720, Erik Werlauff, supra note 2, p. 122.
} 
the area, or other similar areas. A survey can only be requested by the parties, and the experts who conduct it must live up to a number of requirements of impartiality.

\section{Evidence in General}

As already mentioned, Danish civil procedure is governed by the principle of free assessment of evidence. For this reason, establishing a hierarchy of evidence in Danish law is really not possible. No formal rules of evidence exist and no "minimum standard of proof" exists before a fact can be established. Danish law does not provide a list of evidentiary means and the numerus clausus principle does not apply.

Free assessment of evidence provides the parties with a relatively broad scope of possibilities for presenting their evidence. The general understanding is that the parties themselves are the ones who know the specific conditions of their case the best. ${ }^{44}$ Interrogations of, for example, a party or a person affiliated to a firm that is one of the litigants in the case at hand (for instance, a chief executive officer or a director) is therefore considered as an important source of evidence. ${ }^{45}$

\subsection{Interrogation of a Party}

Sections 302-305 of the Act detail the laws governing the procedure for interrogating the parties. According to section 302 of the Act, the court may, upon request of the one of the parties to the trial, request that the counterparty attends the trial in order to answer questions related to the case. Any party may, according to section 303 of the Act, voluntarily present himself and ask for permission to give a testimony before the court. The party who voluntarily presents himself is though obliged to answer further questions which the counterparty or the court may ask him. Most of the rules concerning the interrogations of witnesses also apply mutatis mutandis to interrogation of the counterparty. ${ }^{46}$ However, according to section 305 of the Act, a party who fails to testify does not face the same sanctions as can be issued by the court under section 178 to a witness who fails to testify. ${ }^{47}$ Otherwise, there are no specific constraints surrounding the testimonies of the parties to the case. The court may, however, assess that interrogation of a witness is irrelevant to the outcome of a case, and thus restrict the interrogation of a party, cf. section 341 of the Act.

The procedural format for investigating witnesses in Denmark most often includes a cross-examination. However, a party does not need to give a reason for refusing to testify. If a party elects not to answer questions from the counterpart, this reluctance may, however, have a prejudicial effect (procedural disadvantage) on the counterparty's case, which the court must take account for when assessing the evidence in reaching a judgment.

\footnotetext{
${ }^{44}$ Bernhard Gomard and Michael Kistrup, supra note 5, p. 676.

${ }^{45}$ Bernhard Gomard and Michael Kistrup, supra note 5, p. 676.

${ }^{46}$ See Bernhard Gomard and Michael Kistrup, supra note 5, p. 393.

${ }^{47}$ Cf. Bernhard Gomard and Michael Kistrup, supra note 5, section 677.
} 


\subsection{Duty to Speak the (Full) Truth}

Danish law does not operate with testimony under oath, but if a party or a witness does not speak the truth in court, this may, according to section 158 of the Criminal Code (Straffeloven), be punished with up to four years imprisonment. This provision is applied to the parties as well as witnesses, including expert witnesses. Section 158 of the Criminal Code also applies to witnesses who do not speak the truth in courts outside of Denmark. No specific rules apply as to the evaluation of a party testimony. As noted above, the court may decide that a piece of evidence, such as a testimony, is flawed and thus superfluous, cf. section 341, for instance presentation of settlements and legal opinions that may prejudice the court decision.

There is no rule detailing specific conditions that must be met before evidence may be collected. For the parties, there is also no duty to deliver evidence. If one party asks the other to provide a specific item of evidence, but the counterparty refuses, the court can again deem the refusal to amount to a prejudicial effect when assessing evidence so as to come to a judgment.

On the other hand, third parties are obliged to deliver documents according to the same rules as those for giving a testimony as a witness. Judicial and administrative decisions are also considered as evidence in Danish law. Judicial evidence is for instance a judgment from another court, where, depending on the circumstances, evidence will have been taken under the same (or similar) conditions as the case at hand, and thus may be regarded as facts. If, for instance, a judgment from a criminal case is presented to the court as evidence, the court will review this evidence in light of the fact that the witness testimony would have been given in front of a judge under the normal procedures for questioning a witness. Such evidence will often have a higher standing than administrative decisions, which normally do not include the possibility of interrogating witnesses (although parties to the decision are obliged to tell the truth). However, it does not have the same standing as in Common Law countries with regard to the binding nature of precedent.

\subsection{Burden of Proof}

Once the parties have brought evidence before the court, the court decides which factual circumstances need to be ascertained in order to be able to reach a decision. The court will only examine facts that are not disputed by the parties in the rare cases where the court operates ex officio cf. section 2.2 in the above.

The court evaluates the trustworthiness of a party or a witness, based on the general impression the party makes in court during the hearing, and a survey report or other pieces of evidence do not bind the court. This is implied by the guiding principle of free assessment of evidence as described above.

If a party has the burden of proof regarding factual circumstances, silence or failure to provide the court with evidence relating to these circumstances will be considered to be 
to the detriment of that party, which means that the court may establish something else than what the party claims. As noted above, in determining the burden of proof, the court will first examine the relevant laws pertaining to the case at hand to see whether provision has been made for establishing the burden of proof in the legislation. Normally this is not the case, and the court will then apply some general principles of law in determining the burden of proof. For instance, the burden of proof typically rests upon the party that states that an issue differs from normal procedure ("comply or explain"). Also, the party for whom it is easiest to secure a particular piece of evidence should shoulder the burden of proof for establishing the facts surrounding it. The burden of proof can also switch during the course of the trial.

\subsection{Iura novit curia}

At least in theory, the court is supposed to know and apply the law without relying on the material which the parties bring before it. It is not necessary for the parties to prove what the law is, and the judges can and shall on their own initiative decide which legal rules apply ("Da mihi factu, dabo tibi ius"). ${ }^{48}$ Nevertheless, it is normal practice that the parties express their understanding of the law in written documents and in the oral procedure. On this basis, the court reaches its decision. In the procedural literature, it is, however widely accepted that there is no clear distinction between the facts and the law. Thus, it has been argued that the principle of contradiction restricts the courts' ability to "take the parties by surprise" and decide the case upon a legal rule that may not even have been mentioned by the parties or the court during the hearing. Whether or not the principle of contradiction can be applied as to the law cannot, however, yet be considered decided in Danish law. As already mentioned, the judge may actively participate in establishing that the grounds for the decision are clear and in line with the interests of the parties, cf. section 339 of the Act. ${ }^{49}$ The judge will, however, normally not be obliged to pose questions to the parties before the hearing has taken place, e.g. in a writ of summons. In practice, the judge will often not be aware of the content of all case files until a few days before the first oral hearing, and the questions from the judge will always be posed orally during the hearing or one of the preparatory meetings. Through use of questions, following the provisions of section 339, the court can in effect suggest that the parties elaborate upon certain claims as well as express an opinion on any factual or legal matters as also discussed in section 2.4 above.

\subsection{Re-opening of the Pre-trial Procedure}

The judge may ex officio decide to reopen the case, even after the last hearings have ended and until the final judgement is delivered. If a party does not comply with the court's request for production of evidence, the court may view this refusal in a manner that favours the opposing party when it assesses the evidence. The court is entitled to question witnesses in the courtroom on its own behalf. However, the court is generally not allowed to collect evidence on its own initiative in civil cases. This would be

\footnotetext{
${ }^{48}$ Bo von Eyben, supra note 24, p. 204.

${ }^{49}$ Bernhard Gomard and Michael Kistrup, supra note 5, p. 582.
} 
considered a breach of the principle of party presentation, and in principle also a breach of the principle of impartiality which applies to the judge.

In Danish law, cases involving public law are generally dealt with according to exactly the same procedural rules as private law cases. However, in a small group of cases, dealt with under the Act in chapter 42 (marriage and child custody), chapter 42a (paternity), chapter 43 (guardians) and chapter 43a (administrative imprisonment)), the court is responsible for obtaining the relevant information of the case according to rules of civil procedure, as under section $456 \mathrm{~h}$ inter alia. In these (few) cases, the court decides for itself whether the parties and the witnesses should be interrogated, and it provides expert opinions and other types of evidence. The court itself calls in parties and witnesses. The police assist the court in the taking of evidence in the search for a named possible parent.

Regardless of the procedure, the court is in all phases of the procedure entitled to open the case again until the judgment, and allow the parties to introduce new evidence. It cannot, however, introduce evidence on its own hand, aside from in the small groups of cases cited in the above.

\subsection{Written Evidence}

Following the aforementioned rules on discovery (section 298-299 of the Act), both parties are entitled to go to the court and request that the court requests documents from a third party. In Danish procedural law, any piece of writing which is meant to be used as evidence in a case is considered to be a document. ${ }^{50} \mathrm{~A}$ report that describes the factual circumstances in a case may also be considered a document. In legal terminology, a distinction is made between documents and so-called visual pieces of evidence, e.g. video and sound recordings or surveys (as described above). Nonetheless, the same rules apply if a party presents a driving licence (a typical document) or a video film. In line with the principle of free assessment of evidence, all sorts of electronic documents can in principle be used as evidence in court. The authenticity of a document will obviously be of importance in the courts evaluation of evidence. ${ }^{51}$ However, no general rules on proof apply as to the evaluation of electronic evidence in a Danish court. It is therefore not possible to answer clearly whether an electronic version of a document is equal to a hard copy non-electronic version of a document. This will always depend on the circumstances.

\subsection{Electronic Communication}

Public authorities in Denmark have in recent years increased their electronic communication with citizens and they now very often use systems based on, for example, electronic signatures in order to the ensure privacy and security of transactions, communications, and so on. Such systems are regarded as having a high degree of data protection and in the eyes of a judge, these systems will therefore

\footnotetext{
${ }^{50}$ Bernhard Gomard and Michael Kistrup, supra note 5, p. 705.

${ }^{51}$ Ibid.
} 
naturally stand out as even more secure than other systems which do not have the same level of security. This fact may influence a court's evaluation of a concrete piece of evidence. In the law, however, there are no specific rules that bind the court in its free evaluation of evidence. The main rule is that the party who disputes the validity of a signature must prove that the document is false. There are though a few legal provisions that require a witness to confirm the authenticity of their signature. ${ }^{52}$

Audio or visual evidence will often be considered just as important as written documents. Traditionally, no distinction is made between private and public documents in relation to evidence. Whether a specific piece of evidence carries sufficient weight to carry the case will always depend on a free evaluation made by the court.

According to section 348 and 351 of the Act, the parties must detail the documents and other items of evidence that they decide to take to the court. Copies of written documents will normally be added as an appendix to the case file. There is no requirement that the document must be in its original version. Copies of documents will normally be sufficient.

\section{General Rule on the Burden of Proof}

\subsection{Duty to be a Witness}

According to section 168(1), everyone has a duty to give evidence in court as a witness, subject to the statutory exceptions provided for by the Act. It is the duty of the witness to refresh their memories of the events, cf. section 180 of the Act (for instance by checking accounts, letters or other relevant items), and the witness is obliged to present himself to the court and duly answer all questions posed, cf. section 174 . When giving evidence, unless the court gives express permission, a witness is not allowed to wear an article of clothing that conceals their face, cf. section 168(2) of the Act.

According to section 169 of the Act, public servants and others holding public or comparable office must obtain the consent of the public authority they are employed by before giving evidence about matters which, in the public interest, they must treat as confidential in the course of their work. For members of the Danish Parliament, consent must be obtained from the speaker of the Danish Parliament and the relevant minister. Where such consent is withheld, the court may, if the giving of this piece of evidence is found to be essential to the outcome of the case, order the relevant authority to state to the court the reasons for withholding consent, cf. section 169(2) of the Act. If the court then finds that the interest of maintaining confidentiality should yield to the interest of finding and presenting evidence, the court may direct that evidence to be given. However, this does not apply if consent is withheld for reasons of national security, relations to foreign powers or a third party's life or health.

\footnotetext{
${ }^{52}$ Bernhard Gomard and Michael Kistrup, supra note 5, p. 706.
} 
According to section 170 of the Act, when giving evidence would be against the wishes of a person having a right to confidentiality, persons bound by professional secrecy such as religious ministers, medical doctors, defense counsels, court mediators and lawyers, must not be obliged to give evidence about matters having come to their knowledge in the course of the exercise of their functions. The court may though order medical doctors, court mediators and lawyers, but not defense counsels in criminal proceedings, to give evidence where such evidence is deemed to be essential to the outcome of the case. It is a further requirement that the merits of the case and its importance to the party concerned, or to society, are found to justify the giving of such an order. ${ }^{53}$ In civil proceedings though, such an order may not be extended to retrieving information obtained by a lawyer during legal proceedings that he has been entrusted to conduct or when his legal advice has been sought.

\subsection{Related Persons}

According to section 171 of the Act, close relatives of a party do not have a duty to give evidence as witnesses. Similarly, under subsection 171(2), the duty to give evidence as a witness does not apply where the giving of evidence is deemed likely to:

(i) expose the witness to the penalty of the law or harm to his safety or welfare; or

(ii) expose the witness's related parties to the penalty of the law or harm to their safety or welfare; or

(iii) otherwise inflict significant harm on the witness or his related parties.

However, in the circumstances referred to in subsection 171(1) and paragraphs 171(2)(ii) and (iii), the court may order the witness to give evidence where such evidence is deemed to be essential to the outcome of the case, and the merits of the case and its importance to the party concerned or to society are found to justify the giving of such order.

In line with Article 6 of The European Convention of Human Rights, which has been incorporated into Danish law, ${ }^{54}$ the witness will be protected by the principle of selfincrimination. For instance, according to established case law, a debitor will not be compelled to give a testimony if this could lead to self-incrimination. ${ }^{55}$

\subsection{Procedure as to Witnesses}

Based upon the claims of the parties, the court decides whether a witness shall be called in, cf. the court's discretion under section 340. A witness can also be called in informally by the party who wishes to present the witness, or the witness can be called in by the court by summons. ${ }^{56}$ According to section 175, unless otherwise provided, witness summonses must be issued by the court before which evidence is to be given.

\footnotetext{
${ }^{53}$ Section 170(2) of the Act.

54 Act on the European Convention of Human Rights (1992) cf. "Lov om Den Europæiske Menneskerettighedskonvention, lov nr 285 af 29 April 1992.

${ }_{55}^{5}$ See Ugeskrift for Retsvæsen, 2009, p. 479.

${ }^{56}$ Bernhard Gomard and Michael Kistrup, supra note 5, p. 698.
} 
The summons must be served on the witness. If the summons is issued by the court, it will have the summons served on the basis of the information provided by the party in question. In civil proceedings, witnesses are given one week's notice.

According to subsection 175(2), the summons must:

1. identify the witness with sufficient particularity;

2. state the purpose of the summons;

3. state the court before which evidence is to be given;

4. specify the time and place of the hearing;

5. include information about the notice to which the witness is entitled; and

6. include information about the consequences of non-attendance.

According to section 179 of the Act, a witness may not decide not to attend court of their own accord on the assumption that he is entitled to refuse to give evidence. The court alone will decide this issue from case to case. Normally, the interested party will have the possibility to contest the court's decision to bar or accept a particular witness at the High Court or Supreme Court.

Persons who cannot be expected to give a reasonable testimony should - according to case law - not be called as witnesses. ${ }^{57}$ Children can be called in as witnesses, but they do not face the same sanctions for not testifying as an adult would, as provisions concerning, for example, imprisonment in case of reluctance towards testifying will not apply to them. If a person who is unfit as a witness is for some reason summoned to the court anyway, the court can dismiss that witness with reference to its discretion under section 341 of the Act as mentioned above. As to the witnesses, the court will have to take a decision on a case to case basis, while more detailed provisions of the Act regulate when witnesses can refuse to give evidence. There is though, generally no discretion left to the judge to decide whether or not a party is fit to testify as a witness. The judge must simply decide whether or not the conditions of the law apply.

According to subsection 171(1-3), a witness is amongst others not obliged to give testimony if this would cause the witness or relatives/friends of the witness punishment, damages or "significant harm".

It is not possible to state which sorts of secrets are likely to inflict "significant harm" if revealed. The provision covers a broad spectrum of possible scenarios. If, for instance, a CEO refuses to testify about certain facts claiming that this represents a company's business secret, the court will make a concrete assessment on the facts, where it is free to come to a decision on this matter. If the company is a holder of a concession or public service the result would be the same, since the company will be considered a "private" company in the understanding of the Act. If, however, the question concerns a public law entity, specific provisions apply as detailed under section 169 of the Act, and outlined above in part 5.5.

${ }^{57}$ Bernhard Gomard and Michael Kistrup, supra note 5, p. 682, cf. Ugeskrift for Retsvæsen, 1934, p. 549. 
According to section 172 of the Act, editors and editorial staff employed by a Danish publication are not subject to a duty to give evidence about the identity of the source of a piece of information, the author of an article, or the identity of the person who has taken a photograph or otherwise produced a pictorial representation. If the information has been published, for exemption from the duty to give evidence to be granted, the source, author, photographer or producer must not be identified in the publication. Similarly, the subject of the publication must remain anonymous or not be identifiable by any images for the exemption to be applicable, but the subject must also have provided their account under the condition that they would remain anonymous. The same exemptions and conditions also apply to non-written publications, i.e. radio or television broadcasts.

\subsection{Obtaining Evidence from Witnesses}

The requirement to take an oath was repealed following amendments to the Act in 1965 . $^{58}$ Nonetheless, before questioning of the witness begins, the court will impress upon the witness the duty to speak truthfully and inform the witness that the giving of false testimony is a punishable offence, cf. section 181. The witnesses are interrogated one by one, and as already noted, a witness that has not yet been interrogated is not allowed to hear the testimony of the other witnesses, unless something else is decided by the court in general with the consent of each party. 59

According to section 183(1), the party that calls the witness is given the first chance to examine the witness. The counterparty is then entitled to cross-examine the witness, after which the party that called the witness may then ask the witness the questions which arise as a result of the cross-examination. The court may then allow additional questions to be asked or for the examination to be resumed. The court may also question the witness. Furthermore, the court may take over the examination if the parties' examination of the witness is conducted in an improper manner or in a manner contrary to the provisions of section 184(1) or where otherwise required by circumstances. The court will direct the manner in which and by whom children under the age of 15 are to be examined. The court may call in a representative of the municipal council, or another suitable person, to assist during the examination.

\subsection{Written and Oral Statements}

The parties are not prevented from submitting documents, consisting of just facts and without an index, that were written by a person called as a witness. ${ }^{60}$ Interrogations will not normally be permitted in order to obtain information that could more easily be provided by sending scripts of protocols or declarations made by the witness. It is widely recognized that if a public institution or a private company sends a written

\footnotetext{
${ }^{58}$ Bernhard Gomard and Michael Kistrup, supra note 5, p. 683.

${ }^{59}$ Bernhard Gomard and Michael Kistrup, supra note 5, p. 700.

${ }^{60}$ Bernhard Gomard and Michael Kistrup, supra note 5, p. 683.
} 
declaration which is considered reliable and sufficient, an interrogation of the parties is not necessary. ${ }^{61}$

In civil cases, there are no restrictions as to access to the witnesses. Thus, the attorney representing one of the parties may in advance of trial prepare the witnesses. According to section 158 of the Danish criminal code, perjury, including perjury performed by telecommunications, is punished by up to four years imprisonment. This provision also covers perjury committed before a foreign court.

\subsection{Taking of Evidence}

The taking of evidence occurs during the main hearing after the pre-trial procedure has ended. Thus, as described above, the judge may reopen the case for new testimonies even after the oral procedure has taken place. The parties will normally themselves bring the evidence and witnesses to the court, and a specific request by the court is not needed. Like other areas of the Danish procedure, this is dealt with rather informally. In contrast to the introduction of new claims and arguments, as detailed above, no specific deadlines are specified that restrict the parties as regards introducing new evidence. The preparation of the case may in principle be reopened, and new evidence may be brought before the court until the final judgment is delivered. However, if a party misses a deadline specified by the court, the party may risk that the court will not allow that piece of new evidence is brought into the case.

In the event that the court decides that a certain piece of evidence is irrelevant, following its discretion under section 341 of the Act, the court does not have to give specific reasons for this. That being said, when handing down its judgment, following section 218 of the Act, the court must set out the reasoning behind its decision and therein may stress the relative importance it places upon a certain piece of evidence.

\subsection{Identification of Evidence}

No specific requirements apply as to evidence status in Danish law. Facts that have been proven in another court case will normally have an obviously strong value as evidence, and will normally be allowed to be produced by the parties. The evidence is taken during the hearing, and the principle of directness applies to the procedure. The evidence is presented before the judge by the parties. The judge cannot be replaced by any other person, but an expert who performs a survey (syns- og skønsmand) may, for instance, in a case concerning land law, visit the disputed real estate and provide the court with a written or oral testimony.

Danish law operates with a distinction between direct and indirect taking of evidence. ${ }^{62}$ If the taking of evidence takes place without any intermediaries it is considered direct. The Act also allows indirect taking of evidence, for instance audio or video recordings of testimony given by parties, witnesses or experts. Witness or expert testimony given

${ }_{61}^{61}$ Bernhard Gomard and Michael Kistrup, supra note 5, p. 684.

${ }^{62}$ Bernhard Gomard and Michael Kistrup, supra note 5, p. 670. 
by video-link or similar permitted live telecommunication method (e.g. telephone calls, video calls, etc.), constitutes indirect evidence.

As noted in subsection 186(2) of the Act, when writing up witness testimony evidence for the official court records, it is important to as much as possible, note the witnesses words verbatim. However, it is also noted in subsection 186(2) and (3) that when recorded evidence is produced as evidence, or a witness testimony made in court is electronically recorded, it is not necessary to record the details in the official court records.

\subsection{Procedure for Video Communication}

Following the provisions of section 192 of the Act, when testifying via video telecommunication, the witness must appear before a court, or before an authorized public authority or natural or legal person. Authorization to make video communication equipment available for use in legal proceedings is granted by the Danish Court Administration (Domstolsstyrelsen). The authorization may specify the terms for the carrying out of such telecommunication. Danish Court Administration prescribes detailed rules on the granting and withdrawal of authorizations and on the laying down of terms as well as rules on the payment for telecommunication etc. The court may allow a witness abroad to give evidence by use of video communication equipment if it is deemed that his evidence may be given in the same secure manner as evidence given by telecommunication in Denmark.

\subsection{Expert Witnesses}

If a request for an expert report made in civil proceedings is granted by the court, the court will appoint one or more experts. The court may only appoint persons residing outside of the court's jurisdiction if the appointee has indicated their willingness to serve as a court-appointed expert or if it is deemed necessary by the court. This may be the case if either there are no experts available within the court's jurisdiction or because the subject-matter of the expert report lies outside of the court's jurisdiction. ${ }^{63}$

Only persons of unblemished reputation may serve as court-appointed experts, and furthermore, persons who would be disqualified from sitting as judges in the case may in no circumstances serve as court-appointed experts. Any person who is under a duty to give evidence as a witness is also under a duty to serve as a court-appointed expert, as per section 197 of the Act. However, public servants, both senior and junior, will be excused from serving if the court is informed by letter from the public authority that employs them that the public servant concerned does not have the time required or that such duty would otherwise conflict with their public service duties.

${ }^{63}$ See section 196. See also Bernhard Gomard and Michael Kistrup, supra note 5, p. 621. 
If serving as a court-appointed expert would cause great trouble or inconvenience, the persons in question should, if circumstances permit, be spared the duty of such service. The same applies to persons aged 65 and above. ${ }^{64}$

Each party is entitled to submit recommendations to the court on the choice of experts, but the court is not bound by such recommendations. Before appointing the experts, the court should inform the parties of the persons it intends appointing and allow the parties to submit their comments. ${ }^{65}$ In civil proceedings, objections that are not raised immediately on appointment may be taken into account only if the party informs the court that he was unable to raise the objection at an earlier point in time through no fault of his own. The party intending to raise such objections must convene the opposing party to a meeting in the appointing court within one week of the appointment and raise his objections there. The court order is not appealable if the objections are allowed; if the objections are dismissed, an interlocutory appeal may be filed against the court's decision. $^{66}$

Court-appointed experts must submit their evidence in a written report addressed to the court and signed by the experts. The experts may be asked to give additional evidence before the court; in addition, if the expert report is found to be deficient, the court may direct them to carry out the inspection again or complete it in an additional written report.

The fact that an expert report has been submitted does not preclude another expert report on the same subject-matter from being made by the same experts or, where deemed appropriate by the court, by other experts. ${ }^{67}$ If so directed by the court, the experts are entitled to a fee for preparing the expert report, attending court, and to have their expenses reimbursed.

If there are deficiencies in the drafting of the report, the court should provide the experts with the necessary assistance to rectify such deficiencies. If so requested by the experts, and if circumstances generally so warrant, such assistance may also be provided before the court hearing at which the experts will confirm their report. In such case, the parties must be notified no later than at the court hearing in question.

A report may be drafted by a panel of experts appointed for that purpose. No more than one of the experts should usually be required to attend any court hearing, though in the case of dissent, at least one expert representing each opinion of the panel should attend; the panel decides which experts will attend the hearing. Where a report is submitted by two or more experts, the report should state each expert's opinion in case of dissent.

Court-appointed experts are examined in accordance with the general provisions applying to examination of witnesses. However, court-appointed experts may usually be

\footnotetext{
${ }^{64}$ See Section 198.

${ }^{65}$ See Section 200.

${ }^{66}$ See Section 200(2).

${ }^{67}$ See Section 209.
} 
present during the examination of other court-appointed experts as well as of witnesses, and the court may allow them to consult with each other before answering the questions.

The court appointed experts can only carry out their task if requested to do so by the parties, however according to section 339(2) of the Act, the court may suggest to the parties that they appoints experts.

The scope of the task must clearly be described for the expert witnesses. It must either include questions drafted by the parties in collaboration, or the individual questions raised by each party. The questions must be clear and precise and they must not be too general or concern a legal opinion. When appointed, an expert witness is required to finish the task they were appointed to, thus the expert witness cannot elect to stand down from their duty, for instance because of disagreements with the parties. The court can deploy the same sanctions against an expert witness as against other witnesses. The result of a technical investigation (a private expert report) which a party has asked for of their own accord is not generally regarded as having a high evidential value. ${ }^{68}$ Nevertheless, in recent case law, the Supreme Court has allowed each party to present expert opinions, especially those that have been requested before the hearing.

The fee which the court-appointed expert is entitled to is established by the court. It is normally based on a fee estimate from the expert. Experts expenses are borne by the party that asked for it, but the costs may be refunded according to the rules on legal expenses. $^{69}$ The parties can always suggest a new expert appointment, and if deemed appropriate, the court will normally follow the suggestions of the parties. In principle, however, the court is not bound by any suggestion by a party regarding the appointment of witnesses. ${ }^{70}$

However, following the principle of free assessment of evidence, the court is not obliged to follow any expert report. The court can always require the expert to reevaluate the object, or even appoint new experts, if the court is unsatisfied. ${ }^{71}$

\section{Costs and Language}

As per section 312 of the Act, at the end of the trial, the court decides whether or not the legal expenses (sagsomkostninger) must be covered by the other party or parties (normally the losing party), and if so, the amount that must be paid. ${ }^{72}$ The court always decides the questions of cost, regardless of whether or not the parties claim them. ${ }^{73}$

Only "necessary" expenses may be refunded. Whether or not an expense has been necessary is determined from case to case. Normal expenses include: transport,

\footnotetext{
${ }^{68}$ Bernhard Gomard and Michael Kistrup, supra note 5, p. 722.

${ }^{69}$ Bernhard Gomard and Michael Kistrup, supra note 5, p. 732.

${ }^{70}$ See Section 200(1) of The Act.

${ }^{71}$ Cf. Ugeskrift for Retsvæsen, 1979 p. 654.

${ }^{72}$ Bernhard Gomard and Michael Kistrup, supra note 5, p. 769.

${ }^{73}$ Cf. section 322
} 
translation of documents, ${ }^{74}$ production of a casebook for the court, ${ }^{75}$ and expenses related to the witnesses. ${ }^{76}$ The party that loses the case must pay for the other party's expenses unless the parties have agreed otherwise, cf. section 312. The court may, however, in special circumstances decide that the party that loses the case shall not pay the other party's expenses, or only pay parts of the counterparty's expenses.

Section 311 of the Act provides that each party must make a provisional payment of the costs incidental to the procedural steps taken or requested by that party. The court may also, upon request from one of the parties, require the counterparty to contribute to the costs of, for instance, an expert report, if the counterparty's questions to the expert witness have contributed significantly to increasing the costs.

The court will determine the proportion each party must pay in a provisional division of the costs incidental to the procedural steps ordered by the court on its own initiative. If the party is not represented by counsel, the court may direct the party to provide security in a form and amount to be determined by the court before a procedural step is taken.

Compensation for a witness appearing before court includes travelling costs and a modest payment of 40 DKK (approximately 5 EUR) per hour (though a minimum of 80 DKK). If the witness incurs a loss over this amount, or has specific costs, the court may award a certain amount of compensation. ${ }^{77}$ If an interpreter is appointed to the proceedings, the fee is at present DKK 557.70 (approximately 75 EUR) for each initiated hour. Such costs will normally be reimbursed after the proceedings.

\subsection{Use of Interpreters}

Danish interpreters can have various linguistic backgrounds, however it is normally required that they have taken an exam as a translator, either at an academic institution or independently. According to guidelines published by the Danish Court Administration, the judge must make sure that the interpreter is not impartial. The judge should also be confident that the interpreter knows about the facts of the case, and give the interpreter the best possible information, in order to facilitate the best translation. ${ }^{78}$ According to section 149 of the Act, the language of the court is Danish. Therefore, as far as possible, translators must be provided for those who do not speak or understand Danish. In civil cases, however, an interpreter can be omitted if both parties agree and if the court is confident operating in the foreign language. The parties and the court can also agree to omit the translation of documents to Danish. The expenses of the translations are held in accordance with the normal Danish rules on legal expenses, as outlined above.

\footnotetext{
${ }^{74}$ See Ugeskrift for Retsvæsen, 2010, p. 1978.

${ }^{75}$ See Ugeskrift for Retsvæsen, 2009, p. 137.

${ }^{76}$ Bernhard Gomard and Michael Kistrup, supra note 5, p. 774.

${ }^{77}$ Bekendtgørelse nr. 712 from 17 November 1978, "Om ydelser til lægdommere og vidner mv".

${ }^{78}$ Cf. Bekendtgørelse 1992-01-17 nr. 29 om eksamenskrav for beskikkelse som translat $\varnothing$ r og tolk.
} 


\section{$7 \quad$ Unlawful Evidence}

\subsection{The Principle of Free Evidence}

The principle of free evidence dictates a less strict view on formality within Danish civil procedure, compared to, for example, certain common law countries. The general opinion is that since no rule within Danish civil procedure forbids illegally obtained evidence, such evidence may under some circumstances be produced. ${ }^{79}$ In an announcement written by the permanent Danish advisory board on civil procedure (Retsplejerådet) from 1972, it was stated, that "in civil cases and criminal cases it may occur, that the use of evidence may be justified even if there is doubt about the validity of evidence and even if evidence has been taken by means that are dubious or illegal, for instance because it is obtained from a witness who has listened by the door or by a window or because the evidence produced has in fact been stolen". "Case law within this area is fairly limited. In a provisional judgment from 2001, the Eastern High court implied that in some cases, it may be a possibility to use the above mentioned discretion under section 341 and reject the evidence if evidence has been illegally obtained. ${ }^{81}$ Nevertheless, depending on the circumstances, the court might allow the evidence, even if it has been obtained illegally. The discretion permitted under article 341 to accept unlawful evidence is, on the other hand, subject to the rights guaranteed in the ECHR, including the rights of third parties.

No case law exists as to the use of polygraphs in Danish courts. However, in light of procedural law in other Scandinavian countries, it has been claimed in a Danish procedural law article, that such evidence would be rejected cf. section $341 .^{82}$

\footnotetext{
${ }^{79}$ Martin Gräs Lind, Ugeskrift for Retsvæsen, 2004 p. 85, Den civile retspleje, p. 462.

${ }^{80}$ See Martin Gräs Lind, supra.

${ }^{81}$ Ibid.

${ }^{82}$ See Peter Garde, Festskrift til Jørn Vestergaard, p. $135 \mathrm{ff}$.
} 
Evidence in Civil Law - Denmark

Frederik Waage and Michael Herborn

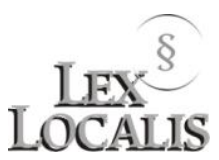

\section{Part II - Synoptical Presentation}

\section{$1 \quad$ Synoptic Tables}

\subsection{Ordinary/Common Civil Procedure Timeline}

The parties' rights correspond with their obligations. The court's neglect of its duties may result in trial error (tuomiovirhe, rättegångsfel).

\begin{tabular}{|c|c|c|c|c|}
\hline $\begin{array}{l}\text { Phase } \\
\#\end{array}$ & $\begin{array}{l}\text { Name of the Phase } \\
\text { Name of the Phase } \\
\text { in National } \\
\text { Language }\end{array}$ & Responsible Subject & $\begin{array}{l}\text { Duties of the } \\
\text { Responsible } \\
\text { Subject (related } \\
\text { only to Evidence) } \\
\text { and Consequences } \\
\text { of their Breach }\end{array}$ & $\begin{array}{l}\text { Rights (related only } \\
\text { to Evidence) of the } \\
\text { Responsible Subject }\end{array}$ \\
\hline & Application & $\begin{array}{l}\text { Case is opened by } \\
\text { written application } \\
\text { (stævning) from } \\
\text { applicant. The } \\
\text { application is sent to the } \\
\text { court. The court } \\
\text { announces the } \\
\text { application for the } \\
\text { defendant. }\end{array}$ & See Section 348-351 & See Section 348-351 \\
\hline & Preparatory phase & $\begin{array}{l}\text { Various documents } \\
\text { exchanged between the } \\
\text { parties during the } \\
\text { preparatory phase } \\
\text { before the preliminary } \\
\text { hearing. All relevant } \\
\text { evidence must be } \\
\text { present before the end } \\
\text { of the preparation phase. }\end{array}$ & See Section 348-351 & See Section 348-351 \\
\hline & Preliminary hearing & $\begin{array}{l}\text { At the preliminary } \\
\text { hearing (normally a } \\
\text { telephone meeting), the } \\
\text { remaining part of the } \\
\text { preparation phase and } \\
\text { the programme for the } \\
\text { hearing is discussed } \\
\text { between the parties. }\end{array}$ & See Section 352 & See Section 352 \\
\hline
\end{tabular}




\begin{tabular}{|c|c|c|c|}
\hline $\begin{array}{l}\text { Possible isolated } \\
\text { taking of evidence }\end{array}$ & $\begin{array}{l}\text { In the event that isolated } \\
\text { taking of evidence is } \\
\text { conducted, this will } \\
\text { happen before the end } \\
\text { of the preparation stage. }\end{array}$ & See Section 340 & See Section 340 \\
\hline $\begin{array}{l}\text { End of preparation } \\
\text { stage }\end{array}$ & $\begin{array}{l}\text { Court closes the } \\
\text { hearing. }\end{array}$ & See Section 358 & See Section 358 \\
\hline Hearing & $\begin{array}{l}\text { Applicant, defendant } \\
\text { and Court are involved } \\
\text { in the hearing. All } \\
\text { evidence is brought } \\
\text { before the court cf. } \\
\text { principle of directness } \\
\text { (see above). }\end{array}$ & See Section 365 & See Section 358 \\
\hline Deliberation & $\begin{array}{l}\text { The court is responsible } \\
\text { for the deliberation. }\end{array}$ & See Section 365(3) & See Section 365(3) \\
\hline
\end{tabular}

\subsection{Basics about Legal Interpretation in Denmark Legal System}

No protocol and no official translations exist of the Administration of Justice Act. The publisher Karnov Group has partly translated The Act. This is, however, not an official translation.

\subsection{Functional Comparison}

Regulation 1206/2001 does not apply to Denmark.

Denmark is covered by the Nordic Convention on Mutual Assistance in Judicial Matters of 26 April and The Hague Convention of 18 March 1970 on the Taking of Evidence Abroad in Civil or Commercial Matters.

No other international treaties appear relevant within this area.

\begin{tabular}{|c|l|l|l|}
\hline $\begin{array}{c}\text { Legal } \\
\text { of Taking } \\
\text { Evidence }\end{array}$ & National Law & Bilateral Treaties & $\begin{array}{c}\text { Multilateral } \\
\text { Treaties }\end{array}$ \\
\hline $\begin{array}{c}\text { Hearing of } \\
\text { Witnesses by } \\
\text { Mutual Legal } \\
\text { Assistance } \\
\text { (Legal Aid) }\end{array}$ & $\begin{array}{l}\text { See eg. Section 302 } \\
\text { and } 340 .\end{array}$ & & \\
\hline
\end{tabular}




\begin{tabular}{|c|l|l|l|}
\hline $\begin{array}{c}\text { Hearing of } \\
\text { Witnesses by } \\
\text { Video- } \\
\text { conferencing } \\
\text { with Direct } \\
\text { Asking of } \\
\text { Questions }\end{array}$ & & & \\
\hline $\begin{array}{c}\text { Direct Hearing } \\
\text { of Witnesses by } \\
\text { Requesting } \\
\text { Court in }\end{array}$ & See Section 347. & & \\
Requested & & & \\
Country & & & \\
\hline
\end{tabular}


Evidence in Civil Law - Denmark

F. Waage \& M. Herborn

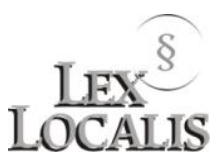

\section{References}

\section{Table of Cases}

Caselaw as quoted in The Danish weekly journal on caselaw (Ugeskrift for Retsvæsen):

Ugeskrift for Retsvæsen, 1934, p. 549

Ugeskrift for Retsvæsen, 1979, p. 654

Ugeskrift for Retsvæsen, 2004, p. 85

Ugeskrift for Retsvæsen, 2007, p. 2993

Ugeskrift for Retsvæsen, 2009, p. 137

Ugeskrift for Retsvæsen, 2009, p. 479

Ugeskrift for Retsvæsen, 2010, p. 1978

Ugeskrift for Retsvæsen, 2011, p. 616

\section{Bibliography}

Bernhard Gomard and Michael Kistrup, Civilprocessen, $7^{\text {th }}$ edition, 2013, p. 31.

Bo Von Eyben, Juridisk Ordbog, 13. Edition, 2008.

C.H. Remco van Rhee and Remme Verkerk in Jan M. Smits, Elgar Encyclopedia of Comparative Law, $2^{\text {nd }}$ edition, 2012, p. 146.

Erik Werlauff, Civil Procedure: Denmark, $3^{\text {rd }}$ edition, 2010.

Johannes Nellemann, Forelфbigt Udkast til Lov om Rettergangsmaaden i borgerlige Domssager med Motiver, 1869, p. 87.

Finn Taksøe Jensen, Materiel Procesledelse, 1976, p. 96.

Henrik Zahle, Det juridiske bevis, 1976, p. 632.

Martin Gräs Lind, Ulovlig tilvejebragte beviser i civile sager, Ugeskrift for Retsvæsen, 2004 p. 85-89.

Peter Garde, Festskrift til Jørn Vestergaard, 2008.

Peter Murphy and Lina Baddour in Karim A A Khan; et al; Principle of Evidence in International Criminal Justice, Oxford University Press, 2010.

Ulrik Rammeskov Bang-Pedersen og Lasse Højlund Christensen, Den civile retspleje, 2th edition, 2010. 